\section{EMERGING LOCAL AUTHORITY NETWORKS WITHIN THE FRAMEWORK OF LOCAL ADMINISTRATION REFORM IN HUNGARY}

\author{
EDIT SOMLYÓDYNÉ PFEIL \\ Centre for Regional Studies of Hungarian Academy of Sciences \\ H-7601 Pécs, P.O. Box 199, Hungary \\ E-mail: somlyodyne@rkk.hu
}

\begin{abstract}
Hungary is struggling with its fragmented local governmental system. The so called "public service reform" aimed to offer equal access to all as regards local public services, as well as to encourage efficiency of activity at local administrative level. The government transferred to local actors the responsibility for the implementation of reform commissioned centrally. The organisational and geographical frameworks for the rationalisation of local public administration were in turn devised at micro-regional level.

This paper mainly aims to analyse urban-rural connections, as co-operative networks of local authorities have already been created. The issue is the extent to which the horizontal cooperations created to organise public services can be effective if their vertical connections are very weak, and, further, if there is no mechanism to counterbalance regional differences.
\end{abstract}

Key words: public administration reform, social cohesion, territorial cohesion, inter-municipal cooperation, network, public services, efficiency.

\section{INTRODUCTION}

Hungary is a strongly centralised unitary (single) state, in which a liberally regulated local governmental system was created in 1990. The local governmental system is built on the settlement network (following the principle of "one settlement, one local authority"), and in consequence is extremely fragmented. Thank to the liberal regulations of the Act on local governments, a part of a settlement with at least 300 inhabitants may request the award of local authority status. Consequently the number of municipalities (local authorities) has been growing steadily since the transition: between 1990 and 2007, 94 new municipalities were born, while the number of local authorities reached 3,175 on 1 January 2008. Fig. 1 demonstrates the fragmentation of the local governmental system and its breakdown by size of municipalities. In the whole of Hungary, 54\% of municipalities have a population of less than one thousand, while the population threshold of 5,000 inhabitants (seen as an optimal number) is only exceeded by $9.2 \%$ of all municipalities. In a European comparison, Hungary is seen to be among those counties that have small municipalities (Verebélyi 1995), with the local governmental level enjoying very strong political legitimacy. It is not surprising that, until a reform of local public services was introduced in 2004, this system operated at high cost and low efficiency. It was simply not suited to the high-quality organization of local tasks.

This essay gives an insight into those changes that have taken place in Hungary as a result of the so-called micro-regional public administration reform. The integrated organi- 


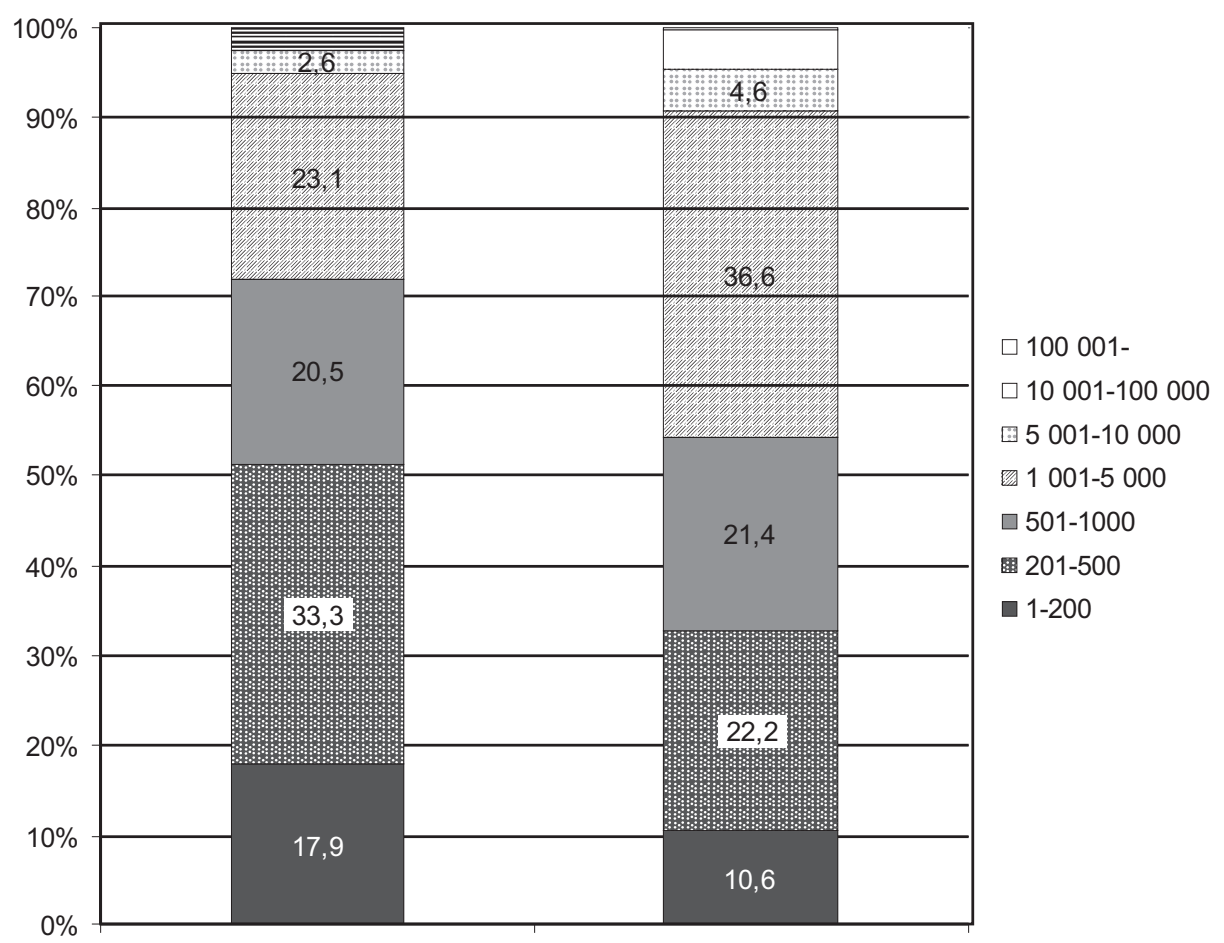

Pécs micro-region

Hungary

Figure 1. Size structure of municipalities in Hungary and in the Pécs micro-region, 2008.

Source: Territorial Database, 2008; CSO Hungary.

sation of local public services is demonstrated by the reference to the gravity zone of a city with a regional centre position, in which it was implemented through the networking of local governments. The basic question posed by the article is whether the horizontal cooperation which can be seen as a model to be followed can operate efficiently if the local level has very weak vertical connections?

\section{THE RELATIONSHIP BETWEEN EUROPEAN TRENDS AND THE HUNGARIAN REFORM}

The Hungarian reform fits in with a trend to be noted internationally. The modernisation of public administration was mainly induced by internal national demand, but the expectations of the EU also had an undeniable effect. Although public administration is one of the competences of the member states, there remains a concept called European Administrative Space, in connection with which the Union has set and is still setting several criteria for public administration in the new member states. Among the Administrative Law Principles published jointly by the EU and the OECD, the principles of the efficiency and effectiveness of public administration should be mentioned as issues of special importance for the topic in question. Both offer a specific dimension to the accountability of public administration. If the state or the municipalities provide services, the efficiency of public administration is of utmost importance for the access of inhabitants to these services (SIGMA 1999). As the Union definitely en- 
courages new member states and accession countries to strengthen their institutional and administrative capacity, it is also stated that the issue of administrative capacities is one of the central concepts of the Europeanisation doctrine (Dragoş-Neamţu, 2007).

In line with the international approach, we can also talk about another European trend also affecting local public administration which started in the reconstruction period following World War II and has not yet been finished with. Within the development of the welfare state, as a consequence of rapid urbanisation and the restructuring of the economy, the rationalisation and reform of the local and regional governmental levels took place for the first time in Western Europe. A central issue in this process was the size and capacity of the local authorities, and not least the democratic character of the local authority administration and the rights of participation citizens enjoyed (Council of Europe, 1995). In the 1950s and 1970s a debate started on whether it was possible to identify an optimum size for local authorities that could secure the minimum level of public services for inhabitants. The surveys relating to this issue had different results in different countries: the South European states preserved the traditionally established boundaries of municipalities, while it was especially the North European countries (Norway, Sweden, Denmark, the UK, Germany etc.) in which the amalgamation of local authorities was carried out, and territorial reform resulted in the founding of large municipalities (Zehetner 1982).

In the ECE region changing the political system, the modernisation of the structure of local public administration became a topical issue in the early 1990s. The problem of the adequate size of municipalities is also a division line in this region: some states preferred fragmentation, while others increased the sizes of municipalities by means of territorial consolidation. In countries with a fragmented municipal system - including Hungary - the right of self-governance for each municipality is seen by central politics as a political and democratic value of the utmost importance. This concept, however, may be based on false ideology, as it is clear that a significant part of the smaller municipalities are unable to offer even the very basic services on their own. Political localism, focusing on the community interests of the municipal governments, is not far from the perceptions of the south European countries, either (Swianiewicz 2001). Mourtizen (2008) points out that the homogenisation of living conditions, the professionalisation of local public administration and the information boom all decrease the positive correlation between the size of municipalities and system capacity. On the other hand, this statement, which is valid for the advanced old member states, is far from being true as yet in several countries of the Eastern European region (Swianiewicz 2010).

We can agree with the opinion that territorial reforms are usually not too often introduced, as it is just the local elites that are the main obstacle to the integration of municipalities. On the other hand, the preservation of spatial fragmentation has far-reaching consequences. One of the most important of these is that spatial fragmentation stops decentralisation and the effective functioning of the municipal governmental system (Swianiewicz 2010). A frequently applied method to counterbalance the system of excessively small municipalities is cooperation among them, i.e. via different associated institutions, a method that is also applied by the Hungarian reform to be introduced here.

The starting point was that, in the one and a half decades since the transition in Hungary, associations were very rarely born out of bottom-up initiatives of the municipalities. If it still happened, then the associations operated and provided the basic functions on various scales in the case of each public service, with ever-changing actors, with various institutional frameworks frequently overlapping with one another, and with consequent zero effectiveness (Fekete-Lados-Pfeil-Szoboszlai 2002).

Hungary in general belongs to that group of transition countries (besides the Czech Republic and Slovakia) insisting on the preservation of a fragmented munici- 


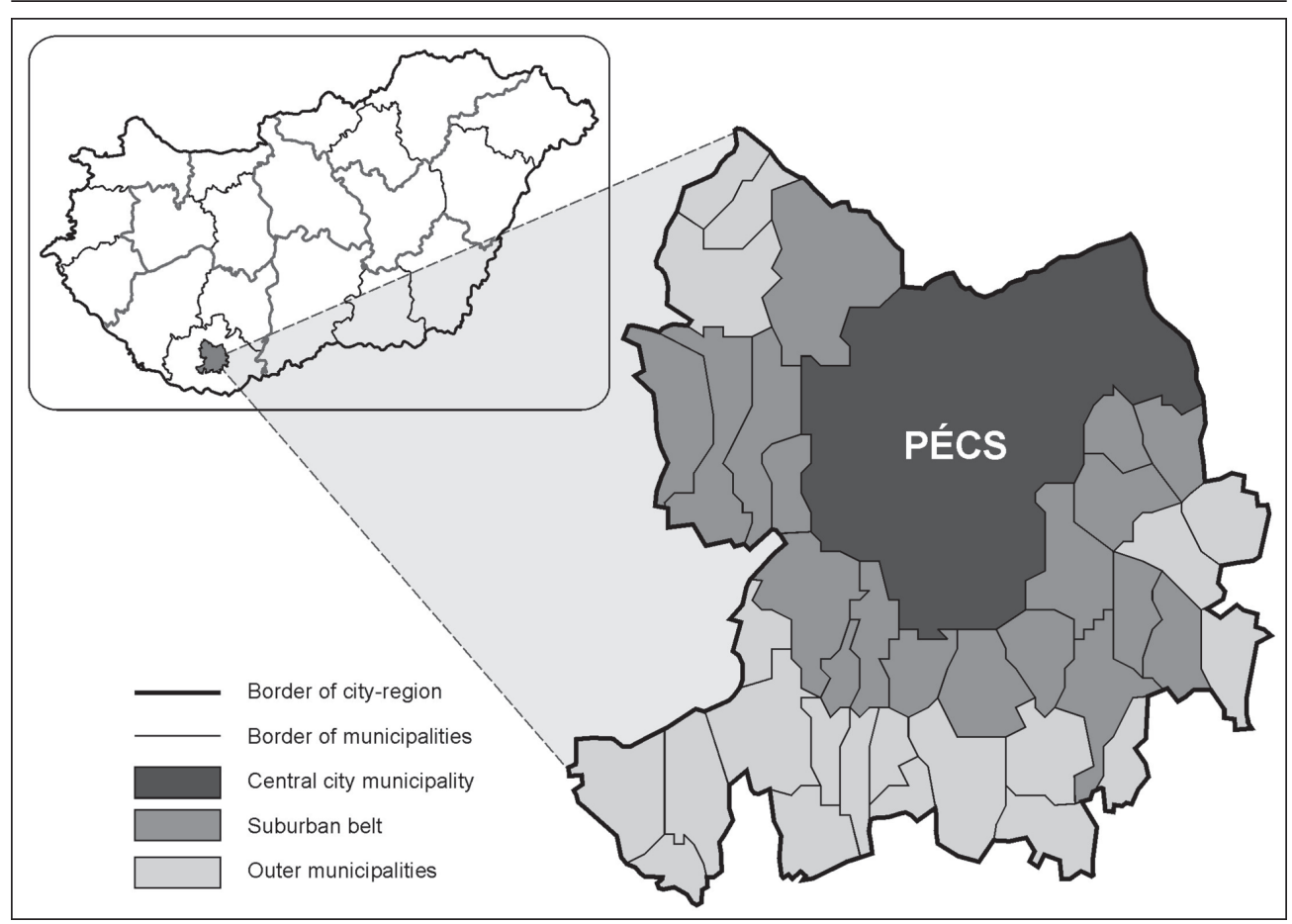

Figure 2. A cooperation network as exemplified by Pécs micro-region.

Source: Compilation from the author on the basis of CSO (Hungary) data.

pal structure. The so-called micro-regional administrative reform introduced in this essay is thus rather contradictory. On the one hand, it tries to make us believe that the missing administrative capacities of the municipalities can be created by a bottomup building model, through the voluntary cooperation of the municipalities. On the other hand, it does not deny that it wants to make alive and operating a significant part of the - perhaps too many - public service functions delegated to the local level by law. Evidently, the latter objective is against cost efficiency. In a peculiar way, the aspects of effectiveness and cost efficiency seem to have become less important over the years, in contradistinction to the declared objectives, and an assessment of them has still not been made.

\section{OBJECTIVES AND OPERATIONAL MECHANISMS OF THE REFORM OF LOCAL PUBLIC SERVICES IN HUNGARY}

The reform targeting the primary level of the local governmental system was actually implemented as an isolated intervention; hence its being termed a reform of local public services. However, it would have been integrated into the wide reform process of public administration according to the plans, and these plans originally envisaged the introduction of elected regional governments in Hungary and the financing the reform of local authorities as well. However, in the absence of a political consensus, the Parliament had only one possible direction to go in, introducing the so-called micro-regional public administration system. The reason for this is the fact that the tool behind the implementation of local public-services reform is 
now the institution of multi-purpose microregional associations, which is built on the voluntary association of municipalities, as the Hungarian Constitution does not empower the state to make municipalities cooperate. Consequently the state has an effective financing mechanism to promote the cooperation of the municipalities. The cohesion power behind the new cooperation is financial need. This means that the state extends normative support to the provision of certain basic human public services. Under the new promotion system, the level of the automatic normative has been decreased and the resources necessary for task provisioning are only transferred to the municipalities in the form of the auxiliary normative if they are able to prove that the tasks are pursued jointly, within the framework of a municipal association.

The geographical framework of the institution of multi-purpose micro-regional association was defined by the legislator by force, linking the associations to the system of the so-called statistical micro-regions, which is actually the LAU1 level under the EU nomenclature. Presently there are 174 statistical micro-regions in Hungary, but their number has been growing continually. The Hungarian Central Statistical Office first designated the boundaries of the micro-regions in 1994, by means of the designation of the primary and secondary gravity zones of the towns and cities (with 138 units originally). In this way, rather homogeneous spatial units were created, and as early as in 1997, these units were serving as bases for the designation of areas eligible for regional development. In this way, the micro-regions became spatial units for intervention, as they reflect in a marked way the spatial disparities existing within regions. The population sizes of the microregions and the numbers of constituent municipalities in fact differ very markedly, the smallest micro-region having 7,000 inhabitants, while the largest is home to 273,000 . The said number of municipalities per region in turn ranges from 2 to 65 ! It should actually be taken as a step forward that, in 2004, each statistical micro-region also became a spatial unit of organisation of public administration, not only being of relevance to regional development. $^{1}$

The reform of the micro-regions led to a definining of important objectives at the local level of Hungarian public administration, i.e.:

- integrated organisation of local public services and provision of the efficient operation of local public administration;

- an assurance regarding equality of citizens' access to local public services;

- the provisioning of a higher and standard level of public services in all settlements of Hungary.

The explanation for these objectives is that the Hungarian government admitted for the first time that local public-service provisioning was far from being complete. Although these are obligatory tasks of the municipalities, failure to provide the services in question has never actually given rise to any legal consequences in the time since the transition (which is to say that the state simply ignored the problem for a long time). Accordingly, serious deficiencies in the provisioning of services could be seen, as this was seen to depend, not only on administrative capacity, but also on the level of political will being displayed by the municipalities. In the new millennium, it became evident that Hungary could no longer maintain and finance the fragmented structure by which public services were being organised in each settlement. Consequently, operations at local governmental level were to be made more efficient and cost-saving through the establishment of cooperations. In line with the concept, the organisation of service provision in larger base units would be able to generate population sizes large enough to make the pursuit of tasks economic. Overall, the establishment of the micro-regional public administration can be seen to have led directly to the appearance of an objective of creating social cohesion, and

${ }^{1}$ In Hungary the institutional system of regional development was built out at county and regional level, parallel to but separated from the administrative organs, a fact that raises continuous legitimacy and efficiency concerns. The spatial planning relevance of this situation will be referred to later in the essay. 
indirectly to territorial cohesion. In this process we can obviously sense the expectations of the EU as regards the public administration of the member states, as these stimulated the Hungarian reforms.

The concept of territorial cohesion nevertheless remains the subject of debate. In line with the definition widely accepted for it (Camagni 2007), the concept of territorial cohesion should be added to the content of economic and social cohesion and must be integrated with sustainability. Indeed, territorial cohesion is actually the territorial dimension to sustainability, in this way conveying both positive and negative content. Specifically, it relates directly to the three components of:

1. territorial quality;

2. territorial efficiency;

3 . territorial identity.

What are these factors in reality? In our case, both territorial quality and territorial identity are important, because (in Camagni's view at least) the first involves "the quality of the living and working environment; comparable living standards across territories; similar access to services of general interest and to knowledge", while the dominant element to territorial identity is seen to include, inter alia, the presence of social capital, and the capacity to formulate a common future vision (Camagni 2007, 135 p.).

The totality of the objectives listed above can only be achieved through an integrated approach, i.e. the joint development of the three sub-systems based around economic, social and physical-natural factors. No modern society can act without taking these into consideration, because these sub-systems are fundamental elements of collective wellbeing. The integrated approach also entails a need to counterbalance the fragmented decision-making mechanisms both in the public and the private sector. In other words, the implementation of territorial cohesion requires vertical and horizontal cooperation among different levels of governance, and among the representatives of the different sectors within the same territorial frameworks (Camagni 2007, 136 p.).

So the essence of the Hungarian microregion reform is that targeted state supports promote the provisioning of elementary public services in the sectors of healthcare, public education, social welfare, family, child and youth protection, public libraries and municipal internal control. There are few places in which associations actually accepted the provisioning of tasks of a territorial nature, though the legislator did empower them to do this within the framework of associations, e.g. in relation to tasks in environmental and nature protection tasks, drinking water supply, sewage treatment, waste management, spatial planning, etc.

Micro-regional associations are actually a framework for joint service provisioning. These organs appear as the level of task organisation, and they mediate a regional and thereby integrated approach to local public administration. In the micro-regional model, tasks are addressed at local municipal or micro-district level. In other words, services are brought to settlements and citizens, e.g. employing travelling experts and not requiring the mass transport of service users and clients to the micro-regional centre. With a slight exaggeration, the multi-purpose associations are the "logistics base" of the micro-region. Although the financing system gives selected support to the implementation of tasks by multi-purpose associations, this is not in reality favoured by the majority of the municipalities.

The micro-regional scale (gravity zone of towns and cities) is evidently too large for the provisioning of local tasks, so it is typical that the micro-regions are divided into sub-districts and sub-centres in order to optimise task organisation. The organisation of public services within the boundaries of statistical micro-regions is engaged in by a large number of further municipal associations, the so-called micro-districts. These micro-districts actually simulate the absent larger-scale basic local government, as the constituent municipalities together have a total population large enough for optimal provisioning as regards tasks. We have to add here the observation that all national-level political actors in Hungary now reject the idea of the amalgamation of 
municipalities; the absolute sovereignty of the tiniest municipality being taken as an absolute value. Micro-regions are actually not an administrative level, but the associations are the recipients of the support targeted for joint task provisioning, so they work as a kind of financial transfer station.

The new administrative structure created by central state regulation cannot operate systematically, a state of affairs that can be accounted for in many different ways. The multi-purpose associations organise the respective public services in relation to their own or their members' ambitions. This denotes that the micro-regional system is still not a guarantee of access for local citizens to local public services that they have the right to and demand for (Kovács and Somlyódyné Pfeil 2008). The reason for this is very simple. The act on multi-purpose micro-regional associations itself and also its explanation stipulate that the application for state support is not a function of the provision of all public services defined by law within the framework of the multipurpose micro-regional associations. In my opinion, this attitude of the legislator clearly violates basic constitutional values and is evidently incompatible with the principle of both social and territorial cohesion.

It is a very interesting characteristic of the reform measures that the government transferred responsibility for implementation of centrally-ordered reform to local actors. The organisational and geographical frameworks underpinning the rationalisation of local public administration were worked out at micro-regional level, without central official assistance. Consequently the volume and methods of the tasks vary from micro-region to micro-region. Networks covering all fields of local public services have been established in only a few places. As a result of the reform ongoing for five years now, the provisioning of local populations with public services has been improved somewhat, though access to such services remains vert far from complete. It is an obstacle in this respect that Parliament introduced the same uniform model in all micro-regions of Hungary. No distinction was made between the urban and the rural areas, and the position of towns and cities in the micro-regional administration was not defined. This was especially detrimental to the organisation of public services in areas that have several towns (a state of affairs currently characterising $44 \%$ of micro-regions). All the latter have their designated centres, but this status is not accompanied by either competencies or eligibilities. The institution of multi-purpose micro-regional associations thus covers a concept that emphasises the equal rights and the coordinate relationship of the municipalities, trying to exclude any kind of centralisation. We can say then that a multi-purpose micro-regional association is a tool suitable in counterbalancing the fragmented municipal system, on the one hand, and is an artificial creation substituting the spatial organising functions of towns, on the other. The neglect of towns, in fact, or anti-town feelings in general, have historical and political underpinnings in Hungarian conditions. This is a reason why the Hungarian Act on Local Governments does not regulate a special administrative institution for the cooperation of towns and cities and their gravity zones, with the exception of the Budapest agglomeration association (Somlyódyné Pfeil 2009). That said, old member states of the Union (Jouvre-Lefèvre 2002) are joined by certain CEEC countries, including Romania, in the way they take measures to introduce the special institutional model of metropolitan areas (Dragoş-Neamţu 2007).

\section{NETWORKING BASED ON THE ORGANISATION OF PUBLIC SERVICES, AS EXEMPLIFIED BY THE PÉCS MICRO-REGION}

It is clear that, at the launch of the Hungarian micro-regional reform, both the horizontal cooperations among the municipalities and the vertical connections of the local administrative tier were rather weak. It is true, on the other hand, that the new micro-regional model has strongly encouraged the local municipalities to cooperate with each other and network, which I am going to demonstrate by 
the example of the Pécs micro-region. In our case this is the larger geographical unit and also the unit of the organisation of tasks that allows problems of economies of scale in local public administration to be tackled.

The Hungarian urban pyramid is deficient, as Budapest is not followed in the Hungarian hierarchical ranking by large cities (Transnational/National FUA-s) with 300,000-500,000 inhabitants. With regard to the ESPON research (2004), a total of 110 functional urban areas (FUA) have been designated in Hungary, on the basis of which the cities were ordered into four hierarchy categories. The first level of the hierarchy is represented by Budapest, a city considered as a MEGA3 growth district (cities compatible with the MEGA4 level being absent from Hungary); and Pécs - together with four other cities - is designated as a regional centre. So Pécs is a functional urban area of national (and over the longer time perspective, even international) importance. The Pécs micro-region, however, is not identical with the regional gravity zone of Pécs, because this was not actually an objective of the designation of the microregions.

The Pécs micro-region, situated in the southern part of Hungary, is the narrower gravity zone of the city of Pécs, embracing a total of 39 municipalities including the city centre (Fig. 2). Pécs is the fifth most populous city in Hungary with 157,000 inhabitants (and a population density of 962 persons/ $\mathrm{km}^{2}$ ), while all other municipalities of the micro-region together are home to no more than 29 thousand citizens. The city and its gravity zone are considered by Hungarian geography as an agglomeration, but the process of suburbanisation is only typical in the narrower ring around Pécs (including 21 municipalities). The remaining 17 municipalities of the micro-region are small settlements of rural character, with extremely low populations. Several of the latter settlements are peripheral rural villages, something that often works to bar access to public services. The micro-region outside Pécs is made up of municipalities, several of which have no public service own institutions, and hence are unable to discharge their obligatory municipal tasks in the face of a lack of adequate administrative capacity. ${ }^{2}$

If we compare the state of the cooperation among the municipalities of the Pécs microregion at three different times (Figs. 3 and 4), we can see spectacular changes. In 1991 the cooperation space in the gravity zone of Pécs was practically empty. The reason for this is, that following the transition, each municipality strove for sovereignty, and this was supported by macro-politics. In 1997 we identified new, but only scattered and isolated, examples of inter-municipal cooperations. A decade after the transition, in 2000, we could see a slightly improved situation, as the state had built in different stimulating mechanisms for the intensification of cooperation. A few local governmental associations already existed, typically for the joint operation of mayor's offices (notary districts), primary schools, kindergartens, and also family support and children's welfare services. It is striking that the medium-sized city centre, Pécs, had no institutionalised relation at all to the municipalities of its gravity zone. Of course the inhabitants of the villages around Pécs used the urban institutions, but agreements regulating this were not made by the municipalities. This meant that examples of cooperation either existed in isolation in the micro-region, or were not established, so spatial equalisation and the handling of the spill-over effects were not even mentioned. In practice, the quality of service provisioning varied from one municipality to another, and the inhabitants of small villages could obviously only use one-third of the basic public services that the citizens of the large municipalities could use.

The system of the multi-purpose microregional association allowed the municipalities to organise their tasks in an integrated way, in a larger geographical setting. In this

${ }^{2} \mathrm{We}$ only refer to one single datum to support this statement. In 2007, in 22 of the 39 municipalities the local population had no access to even a single basic social service, although the demographical situation of the small villages would have justified access to these services. 

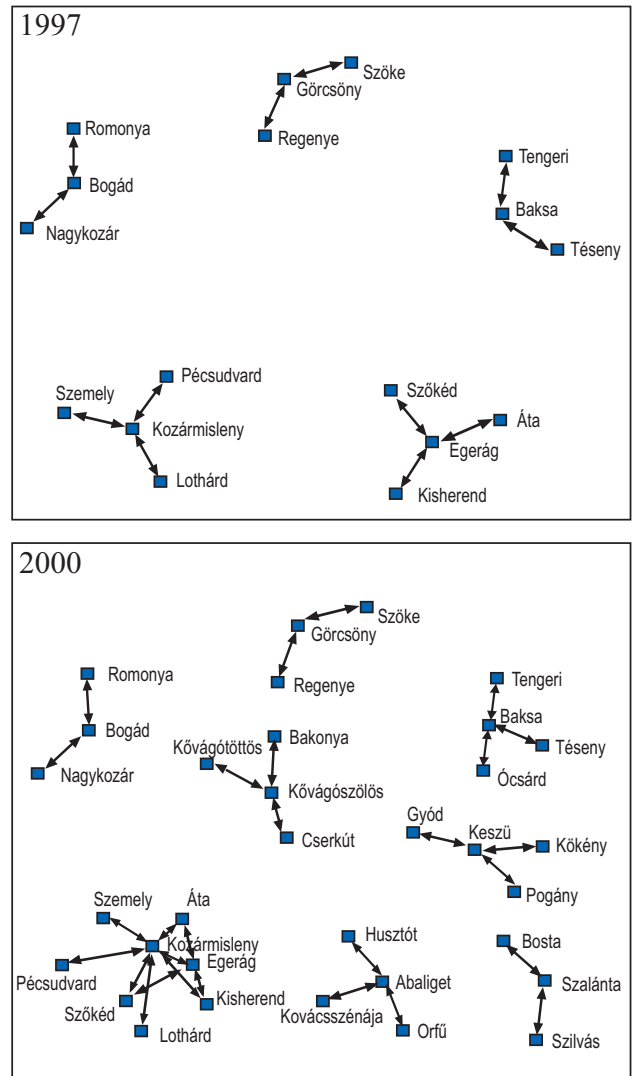

Figure 3. Previous intermunicipal co-operations in the gravity zone of Pécs.

Source: The author's own research

respect and in a national comparison the Pécs-centred multi-purpose micro-regional association is seen to be a model worth following. Through the collection of empirical data we analysed those municipality connections in the Pécs micro-region that had been institutionalised (i.e. underpinned by an association or contract) and which have as their purpose the provisioning of local public services. The number of inter-municipal connections in the micro-region has multiplied, with these assuming a network character at this stage (Fig. 4). The main features of these relations are as follows:

- We analysed the micro-regional association of Pécs from twelve aspects, i.e. by reference to twelve groups of tasks of the local authorities. ${ }^{3}$ The system is specific in the sense that there is the multi-purpose micro-regional association founded by the actors as the $40^{\text {th }}$ element, which is the organising agent and coordinator of cooperation, though this also carries out two tasks for the member municipalities. In the association organised, all $38+1$ municipalities are connected to at least one network actor, so this is a complete network (Csizmadia 2009. p. 148.). However, the big city, Pécs, is not a dominant factor but an equal-right actor in the micro-region. Due to its size, Pécs itself performs most of the administrative tasks for its own population; in some cases also serving the municipalities of the micro-region.

- Fig. 5 points to the existence of and directions to cooperation. We were able to register a total of 772 connections among the members of the Pécs micro-region, but after filtering out multiplications of the relations, 276 edges were registered in the graph. If this figure is compared to the total of 780 possible relations among the microregional actors, we can see that the internal relations density (Csizmadia 2009a) of the cooperation network is $35.4 \%$ (Fig. 5). It is favourable that there is not one municipality in the network that only has relations to Pécs and the multi-purpose association: each municipality cooperates with at least two or more of its neighbours.

- The network clearly featured those microdistricts and micro-district centres that help to optimise the organisation of public services. In another approach, there are municipal "de-centres" emerging in the network, offering different public services for the surrounding municipalities. These sub-centres (Görcsöny, Kozármisleny, Kővágószőlős,

3 The aspects taken into consideration in the analysis, i.e. the fields of joint provision of tasks, were as follows: district notary office, primary school education, kindergarten, public education and library, family assistance service, children's welfare service, selected construction authority tasks, basic social services, after-hours medical care, operation of animal waste deposit, internal control and regional development. 
Orfü, Pellérd and Szalánta) usually gather around them the most helpless, peripheral municipalities, which are unable to cooperate with each other otherwise. These peripheral municipalities, in line with their size, do not have institutions. The directions to relations are here motivated by geographical proximity in the first place.

- The municipalities with intensive relations networks account for approximately seven public services clusters in the micro-region. Of course these hypothetical clusters may vary by respective fields of public service, depending on the participating municipalities. If we add the populations of the municipalities organised into clusters (excluding Pécs), the average population therein is 3,894 . owing to the fact that the point of municipal cooperation from an economic aspect is to generate a population size necessary for the optimal provisioning of tasks, the registered average figure quite successfully counterbalances the fragmented local governmental structure. ${ }^{4}$ This figure should be compared with the average population size of 722 in the 39 municipalities of the Pécs micro-region, apart from Pécs, as of 2008.

- If we attempt to neglect those edges in the network that run out in a radial direction from the multi-purpose micro-regional association and directly from the city of Pécs, we come to surprising results. The network is disintegrated into three partial networks, among which there is no service relation (Fig. 6). However, the members of the partial networks are bound organically to each other with multiple ties. We have to note briefly how the intensive cooperation of the three partial networks is also the result of the intensive organising activity engaged in by the multi-purpose micro-regional association. We do not say then that an integrated system would work

${ }^{4}$ The population in the Orfü-centred cluster is 1,745 , in the cluster centred around Görcsöny 3,690 , around Szalánta 1,555, and in the case of Kővágószőlős 2,641. In contrast, the Kozármislenycentred cluster has 9,522 inhabitants, while the clusters around Pellérd and Nagykozár have 4,519 and 3,588 inhabitants, respectively. at a lower level without the micro-region. In fact, we can say that the central actor imparting cohesion to the Pécs micro-region is either the multi-purpose micro-regional association or the city of Pécs. The partial networks attest to the extension of cooperations within micro-region, i.e. to the municipalities belonging to the decentres of the network being associated with each other. They also justify the assumption that geographical location and transport accessibility determine association relations, as geographical distance clearly explains the fragmented character of the network.

To sum up, the Pécs micro-region clearly shows how the system of multi-purpose micro-regional associations is a centrally institutionalised cooperation, i.e. a cooperation generated by an exogenous factor. However, within the framework of the central regulation, a decentralised model of joint action operates, this resulting in bottom-up built innovations in the operation of the local public administration (Elster 1997). The state has actually managed to force the municipalities to associate (by means of a financial incentive), the result being for the system to operate more effectively and at higher quality. The main beneficiaries of this process are the citizens, who have access to an almost complete range of local public services. What is more, these are in most cases available in their locality of residence, or in the closest micro-district centre (network de-centre). The "benefit" that the municipalities draw is less clear-cut, because local governments providing services for neighbour municipalities receive state support for the tasks provided, albeit with the magnitude of the tasks being increased by the association. On the other hand, small municipalities that have not pursued certain tasks for their inhabitants thus far, now have extra budgetary expenses following the appearance of the new tasks.

The picture at national level is far worse than that in the Pécs micro-region. The State Auditing Office of Hungary conducted a comprehensive survey of the micro-regional administrative system and concluded that 


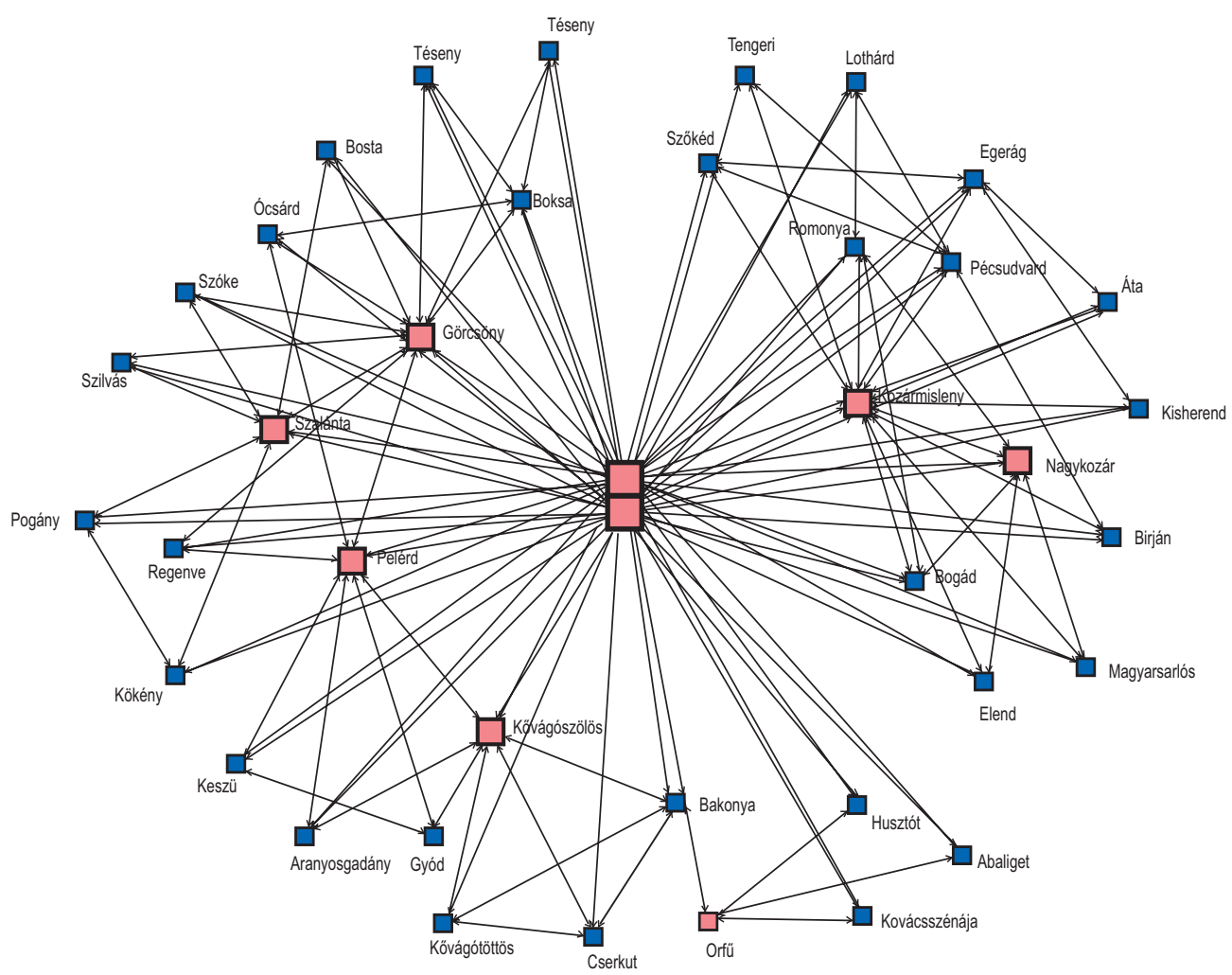

Figure 4. Visualisation of the current network structure in the Pécs micro-region, 2009.

Source: Output of Ucinet 6. (Borgatti, S.P., Everett, M.G. and Freeman, L.C. 2002. Ucinet for Windows: Analytic Technologies).

the Ministry's efforts had failed to mediate needs as regards efficiency and economies of scale through the definition of professional requirements. Another finding concerning the micro-regional system was that, despite increased expenditure, no general progress can be demonstrated in the quality and efficiency of task provisioning. In this way the returns on state expenditure are found to be limited (ÁSZ 2008. p. 20.).

The finding of the empirical survey is that those cooperations which can be identified at the local level of public administration are evidently different from the networks operating in the economic sector. This reflects the fact that, in our case, the benefit of networking is to counterbalance deficiencies as regards the capacities of local authorities.
Although the municipalities participating in the networks are legally equal, they are organised in a hierarchical structure, depending on the functions they provide and the position they have in the settlement network. In fact, the new relations emerging in the framework of the network may lead to further concentrations.

\section{ON THE VERTICAL RELATIONS OF MICRO-REGIONAL PUBLIC ADMINISTRATION AND THE POSSIBLE CORRECTION OF THE MODEL}

Although the micro-regional administrative system is not built systematically around towns, it still reflects an approach originating with the EU, to the effect that the develop- 
Table 1 . Some characteristics of the density of inter-municipal co-operation.

\begin{tabular}{lccc}
\hline & 1997 & 2000 & 2009 \\
\hline Number of isolated nodes & 22.00 & 6.00 & 0.0 \\
Percentage of isolated nodes & 56.41 & 15.38 & 0.0 \\
Centralization index & 6.61 & 10.12 & $44.4^{*}$ \\
\hline
\end{tabular}

*(13.7 w/o Pécs)

Source: The author's own research.

ment of urban-rural relations contributes to territorial cohesion, where territorial cohesion can be taken to be a special case of social cohesion. In this way the urban-rural relations have a mutual relationship with both types of cohesion (Smith and Courtney 2009).

The results of micro-regional public administration are not convincing, being only partial results. The framework regulation arrived at by the government does not guarantee the birth and operation of a standardised local public administration structure. The established micro-regional cooperations - which formally cover the whole of Hungary - have weak vertical relations. The multipurpose micro-regional associations are suitable for evening out the disparities across the quality of services provided by the local authorities within a given micro-region, but the equalisation among the micro-regions does not work. If local public administration built on the micro-region is to turn into a stable and efficient system, several conditions that are missing for the time being will have to be addressed. Specifically:

- The financial conditions of micro-regional public administration are featured annually in the central budget, changing from year to year in an unpredictable manner, and hence not making long-term planning possible. A solution here would be the implementation of a reform of budgetary financing, a development that has been postponed in Hungary for some time.

- While spatial and sectoral planning at micro-regional level is going on in a positive way in Hungary, regional co-ordination and professional control are both absent. The reasons for this lie partly in the fact that the operation of micro-regions has become important preliminarily for the operation of public administration, while the seven NUTS2 regions operate as regional development and statistical units, and have been shaped to be able to access and receive EU funds, while enjoying no self-governing status. As a result, the relationship between the two levels at which regional development takes place is unresolved structurally, as state of affairs that in turn reflects Hungary's status within the group of countries whose institutional system of regional development has been built relatively separately from public administration, and in fact rather in parallel with it. Regional development councils - seven planning statistical regions in NUTS2 units - are not really capable of substantive cooperation, due to their unclear legal status and a lack of own sources of income. If the integration of micro-regional, county- and regional-level planning were to be implemented, this would also be an effective tool for equalisation among the microregions and the achievement of territorial cohesion, as it would supply a territorial frame of reference for the operation of the local public administration.

- In the Hungarian system of public administration there is a lack of resolution in both legal and practical terms of where inhabitants should turn if they have no access to a public service, because their own local authority does not provide it for them. It is not clear which is the organ providing the missing services. State control over the municipalities has been very weak since the transition, so for the completion of the system it is indispensable that the state authorises some of its organs to act if a local government fails to organise compulsory tasks, so that citizens may have real access to the public services they are entitled to. However, this requires that a registry of ob- 

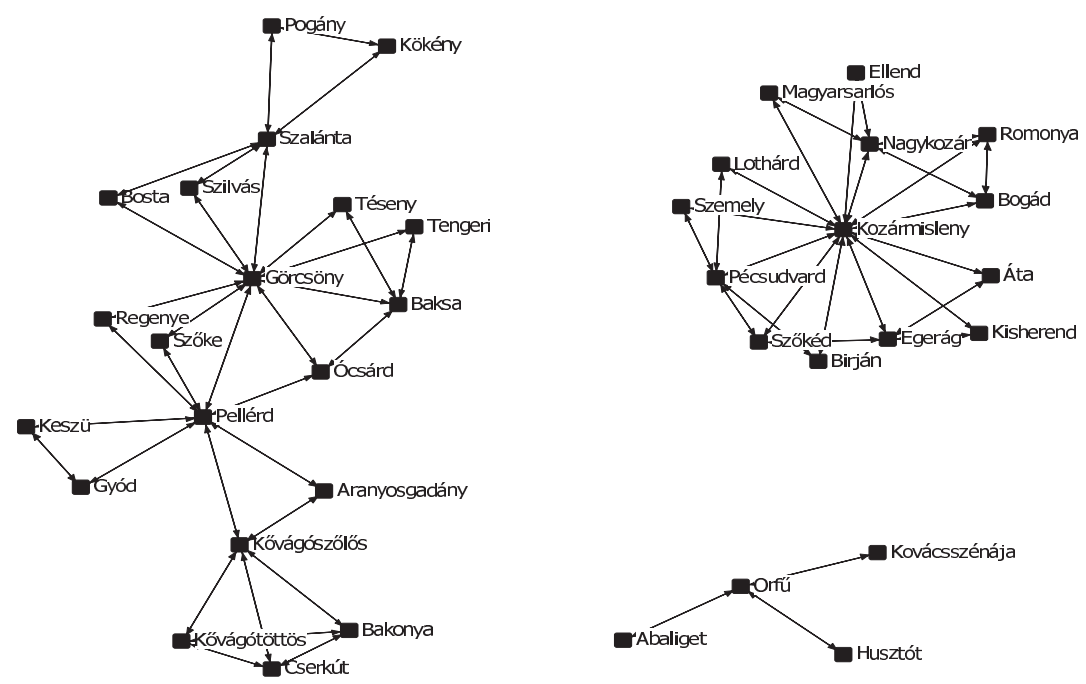

Figure 5. The three main components of the graph following deletion of the two central nodes.

Source: The author's own research.

ligatory services be maintained by each and every municipality, as in the absence of this the problem of full access for the population cannot be handled.

- Though the micro-regional system has existed for just five years, the number of relevant regulations has become excessive and almost impossible to follow. One of the reasons for that is that definitions of support conditions are arrived at separately by ministries, in isolation from one another. It is absolutely necessary to coordinate the sectoral policies of the ministries for the promotion of micro-regional service provision, and the Ministry of Local Governments must be given a strong integrating role in this process.

- Our experiences suggest that the institutionalisation of the cooperation of rural and urbanised micro-regions requires the elaboration of differentiated organisational models, as the totally uniform system has failed to bring the expected results.

- The Parliament unfortunately failed to clarify the relationship between microregional administration and meso-level local governments; meanwhile the specific interpretation of the principle of subsidi- arity allows the multi-purpose associations to take over the compulsory tasks of the county-level governments. Consequently the latter are further weakened in their power and competency.

- In recent years, the state has tried to support the operation of multi-purpose associations by micro-regional bus tenders, but this has only resulted in ad hoc interventions. There should be an examination at central level of how transport development is connected to integrated service organisation, and how access to services might be provided, because the organisation of services at micro-district centres means extra travel demand for both citizens and experts in public administration.

The recommended measures are of course far from being a complete list. It is evident, however, that the parallel application of several methods is necessary if basic local governmental services are to be provided across Hungary at the same level of quality, so that each citizen might enjoy equal access. The introduced micro-regional system of public administration will have a significant contribution to make to the implementation of ter- 
ritorial cohesion in Hungary, if the readiness to cooperation positively on the part of local actors is supplemented by cooperation and coordination among the different levels and sectors of governance.

\section{CONCLUSIONS}

It is important to recall Hungary's status as a new member state of the EU, in which the building up of democracy and the municipal system was a rapid process involving the adaptation of Western European examples, despite the lack of any historical precedents and traditions. New member states are anyway faced, during their state-building process, with challenges by which they skip development phases that were actually experienced by Western European countries (Horváth 2005). We can think in this place of the neo-liberalism operating since the $1980 \mathrm{~s}$, and the consequences of this principle for public administration, via the penetration of the principle of New Public Management. As Wollmann refers to the correlations of this (2006, p. 1430): "The call for market liberalisation and privatisation also found strong conceptual and political backing from the European Commission and its commitment to create and promote the 'single European market"".

The privatisation of public services, and the inclusion of the private sector and the not-for-profit sector into the provisioning of municipal services has been accomplished in Hungary, especially in the operation of the public utilities. ${ }^{5}$ In contrast, the model of the multi-purpose micro-regional associations is getting closer and closer to etatism. In the concept of the related state support system, local public services can most adequately be provided by the own institutions which municipalities and their associations have founded. The not-for-profit sector is actually eligible for much less state support for

\footnotetext{
${ }^{5}$ The analysed model is definitely limited to the organisation of human public services, the maintenance of public utilities (water, sewage, waste collection, remote heating system, public transport, etc.) is beyond its area of competence.
}

the organisation of the same local functions than municipalities are. In this way the state engages in far-reaching intervention in the operation of the local public sector, and does stands in the way of the organisation most suitable for the provisioning of services being selected within the framework of municipal autonomy. In fact, it resembles the historical building up of far-reaching welfare states after World War II, with attendant suppression of local initiatives (cf. Wollmann 2006). Consequently, the Hungarian example shows that, under the cover of inter-municipal cooperations institutionalised by the state, it is actually a networking of municipalities that takes place, while the model is not meant to promote pluralisation of the provision of services. The actors entitled to define the 'common good' are still local actors in public administration.

On the whole we cannot talk about either territorial or functional reform of Hungarian public administration, because the introduction of the micro-regional system was achieved without the structural problems of public administration being taken into consideration. This is the source of the instability and weakness of the system. It applies a continuously changing institutional system without direct political legitimacy, micro-regional associations operating as delegated organs. As it does not allow the micro-regional model to absorb central state functions, this system is not suitable for the breaking down of the centralised state, i.e. for decentralisation, although - not openly - it aims to increase the size of the municipal level.

\section{REFERENCES}

ÁSZ (Állami Számvevőszék [State Auditing Office of Hungary]) (2008), Jelentés a települési önkormányzatok többcélú kistérségi társulásainak a közszolgáltatások és területfejlesztési feladatok ellátásában betöltött szerepének ellenőrzéséröl (2008. július) [Report on the control of the role of multi-purpose micro-regional associations in the provi- 
sion of public services and regional development tasks. July 2008], available from <http://www.asz.hu/ASZ/www. nsf/jelentesek.html $\geq$.

Camagni, R. (2007), Territorial Development Policies in the European Model of Society, in Faludy, A. (ed.) Territorial Cohesion and the European Model of Society, Lincoln Institute of Land Policy, Cambridge-Massachusetts, pp. 129-144.

Council of Europe (ed.) (1998), The size of municipalities, efficiency and citizen participation. Local and regional authorities in Europe, No. 56, Council of Europe Press, Strasbourg, pp. 85-103.

Csizmadia, Z. (2009), Együttmüködés és újítóképesség. Kapcsolati hálózatok és innovációs rendszerek regionális sajátosságai [Cooperation and innovation capacity. Regional characteristics of relations networks and innovation systems], Napvilág Kiadó, Budapest.

Dragoș, D. C., Neamțu, B. (2007), Reforming local public administration in Romania: trends ands obstacles, International Review of Administrative Sciences 73, No. 4: 629-648.

Elster, J. (1997), A társadalom fogaskerekei. Magyarázó mechanizmusok a társadalomtudományokban [The cogwheels of society. Explanatory mechanisms in social sciences], Osiris Kiadó, Budapest.

ESPON (2004), ESPON in progress. Preliminary results by autumn 2003, ESPON, Luxembourg.

Fekete, É.G., Lados, M., Pfeil, E., Szoboszlai, Zs. (2002), Size of Local Governments, Local Democracy and Local Service Delivery in Hungary. In: Swianiewicz, P. (ed.) Consolidation or Fragmentation. The Size of Local Governments in Central and Eastern Europe. LGI (Local Government and Public Service Reform Initiative) - OSI (Open Society Institut), Budapest, pp. 31-100.

Horváth, M. T. (2005), Közmenedzsment [Public Management], Dialóg Campus, Budapest-Pécs.

Jouvre, B., Lefèvre, Ch. (eds.) (2002), Local
Power, Territory and Istitutions in European Metropolitan Regions, Frank Cass Publishers, London-Portland, OR.

Kovács, K., Somlyódyné Pfeil, E. (eds.) (2008), Függöben. Közszolgáltatás-szervezés a kistelepülések világában [Dependants. Organisation of public services in the world of the small settlements], Programme Directorate of Government Centre for Public Administration and Human Resources Services, Regional Operational Programme 3.1.1., Budapest.

Mourtizen, P. E. (2008), The art of the impossible: Reforming local government in Denmark, in Baldersheim, H., Rose, L. (eds.) Territorial Choice: The Politics of Boundaries and Borders, Palgrave Macmillan, London.

SIGMA (1999), European Principles for Public Administration. SIGMA Papers: No. 27. A Joint Initiative of the OECD and the European Union, CCNM/SIGMA/ PUMA(99)44REV1.

Smith, I., Courtney, P. (2009), Preparatory study for a seminar on rural-urban linkages fostering social cohesion, Final position paper, (University of the West of England-Countryside and Community Research Institute) DG Regio, Brussels.

Somlyódyné Pfeil, E. (2009), A befejezetlen reform - a kistérségi közigazgatás értékei és dilemmái [The unfinished reform - values and dilemmas of the micro-regional public administration], $U_{j}$ Magyar Közigazgatás 2009, 1: 33-43.

Swianiewicz, P. (ed.) (2001), Public Perception of Local Government,. Local Gorvernment and Public Service Reform Initiative, Open Society Institut, Budapest.

Swianiewicz, P. (ed.) (2010), Territorial Consolidation Reforms in Europe, Local Gorvernment and Public Service Reform Initiative, Open Society Institut, Budapest.

Verebélyi, I. (1995), European Trends and the Hungarian Way. The Minimum Viable Size of Local Authorities, in Council of Europe (ed.) The size of municipalities, 
efficiency and citizen participation. Local and regional authorities in Europe, No. 5: Council of Europe Press, Strasbourg, 85-103.

Wollmann, H. (2006), The Fall and Rise of the Local Community: A Comparative and Historical Perspective, Urban Stud- ies, Vol. 43. No. 8: 1419-1438.

Zehetner, F. (ed.) (1982), Reformen der Kommunen und Regionen in Europa, Institut für Kommunalwissenschaften und Umweltschutz, Linz. 